\title{
A COMPARISON OF EXPIRATORY AND INSPIRATORY FLOW RATES IN HEALTH AND IN CHRONIC PULMONARY DISEASE
}

\author{
BY \\ R. S. McNEILL, G. D. MALCOLM, AND W. RHIND BROWN \\ From the Department of Pharmacology and Therapeutics, University of St. Andrews, \\ Queen's College, Dundee, and Bridge of Earn Hospital
}

(RECEIVED FOR PUBLICATION JANUARY 26, 1959)

More attention has been paid to the analysis of forced expiratory spirograms than to the inspiratory counterpart, probably because expiration is the more obvious difficulty in chronic obstructive respiratory disease. We believe that a greater understanding of the underlying abnormal mechanisms in the lungs can be obtained from a study of both inspiratory and expiratory spirograms.

The method introduced by Danzig and Comroe and described by Comroe, Forster, Dubois, Briscoe, and Carlsen (1955) for the spirometric analysis of maximum expiratory and inspiratory flow rates has been chosen. It involves the measurement of the time taken to deliver a litre of gas between the first 200 and $1,200 \mathrm{ml}$. of a forced expiration or inspiration and the conversion of this rate to litres per minute at body temperature and pressure and saturated with water vapour (B.T.P.S.). If a rapid kymograph is used the accuracy obtained is comparable to an electrical pneumotachograph at rates up to 400 litres per minute (Comroe and others, 1955). This technique is preferred to the more usual methods of measuring the volume delivered within 1 or 0.75 second because inspiration is often completed within this time.

\section{METHODS}

A spirometer of the Bernstein, D'Silva, and Mendel pattern was used. Following full inspiration or expiration, forced expiratory and inspiratory spirograms were separately recorded. The maximum expiratory flow rate (M.E.F.R. $1 . / \mathrm{min}$.) and maximum inspiratory flow rate (M.I.F.R. $1 . / \mathrm{min}$.) were measured according to the method shown in Fig. 1. The first $200 \mathrm{ml}$. of the spirogram was rejected in order to overcome starting errors due to the inertia of the system.

To assess the variance of the measurement within trials in the same persons, six numbered measurements of M.E.F.R. and M.I.F.R. were made in each of five normal subjects. To compare this with the variance in patients the records of 10 patients were also studied.

For the purpose of relating changes in M.E.F.R. and M.I.F.R. to disability, 61 miners with varying degrees of pneumoconiosis were studied. These miners were from the Fife coalfields and had been referred to the Industrial Chest Diseases Unit at Bridge of Earn Hospital for medical assessment. They formed a homogeneous group in respect of sex, age, and occupation only.

Further experimental studies were performed in three normal subjects and four patients with the clinical diagnosis of emphysema. Spirograms were obtained at varying intrathoracic pressures which were measured by the oesophageal balloon method with the subject in the sitting position. The pressure was recorded through a capacitance manometer on to a
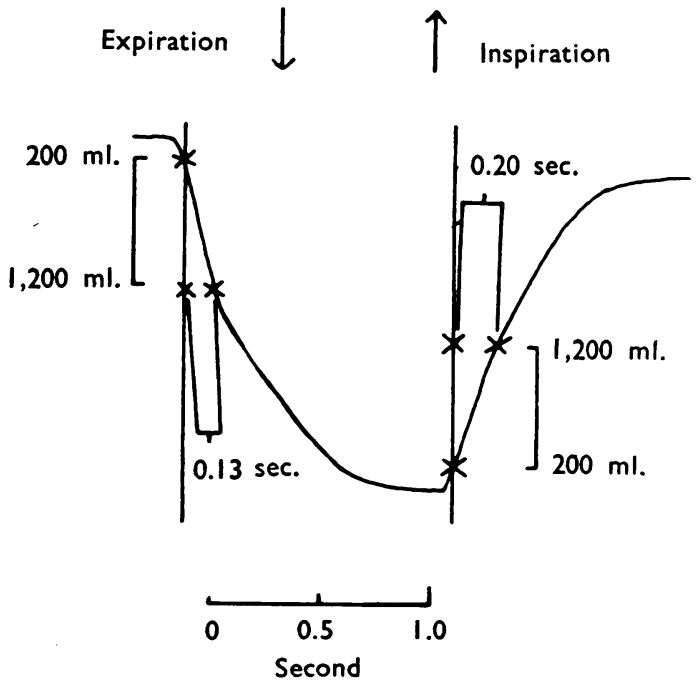

FIG. 1.-Normal forced expiratory and inspiratory spirograms shown together for convenience.

$$
\begin{aligned}
& \text { M.E.F.R. }=\frac{1}{0.13} \times 60=4621 . / \mathrm{min} . \\
& \text { M.I.F.R. }=\frac{1}{0.2} \times 60=3001 . / \mathrm{min} .
\end{aligned}
$$



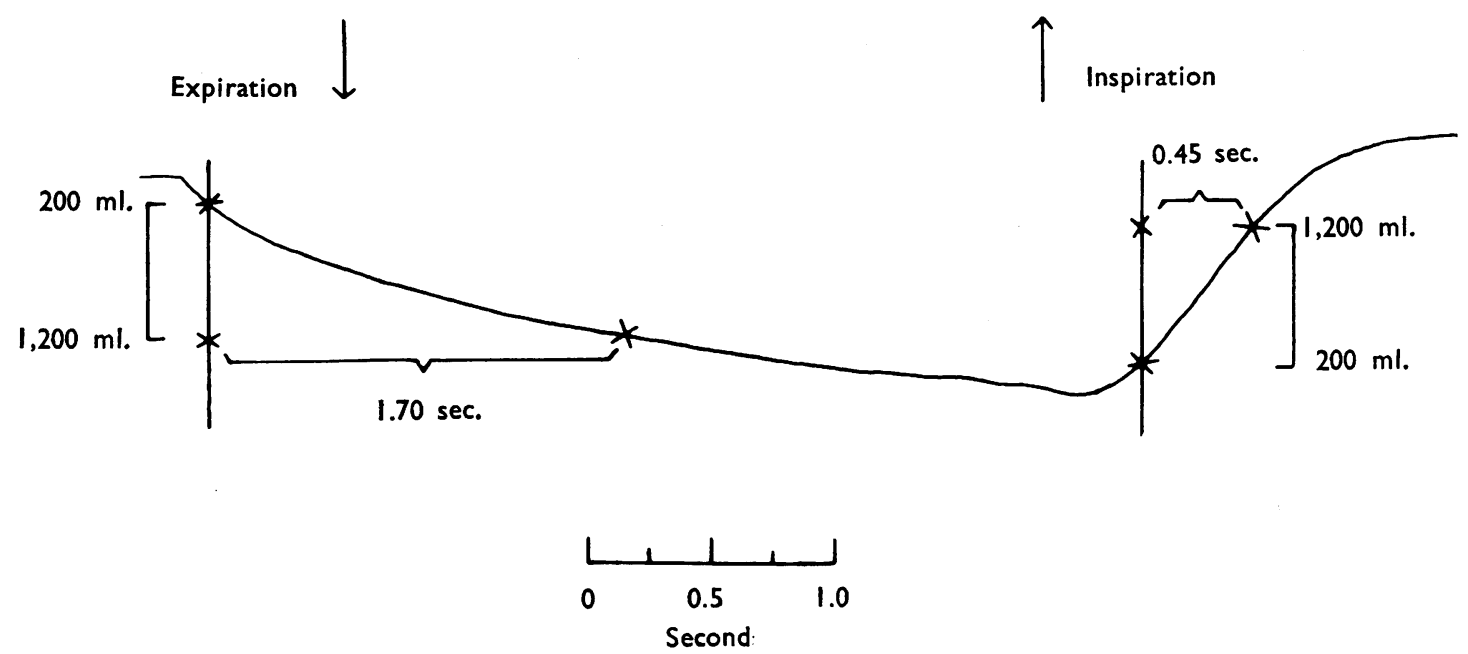

FIG. 2.-Forced expiratory and inspiratory spirograms in a patient with emphysema. M.E.F.R.=35 1./min. $\quad$ M.I.F.R.=133 $1 . / \mathrm{min}$. Note the steeper inspiratory spirogram.

pen and ink writer, and directly above was a volume tracing obtained from a spirometer with a potentiometer attachment. The volume expelled in 1 second was measured and related to the maximum pressure developed during that second.

\section{RESULTS}

The values obtained in the five normal subjects are shown in Fig. 3. It can be seen that to obtain the best M.E.F.R. value there is no advantage in

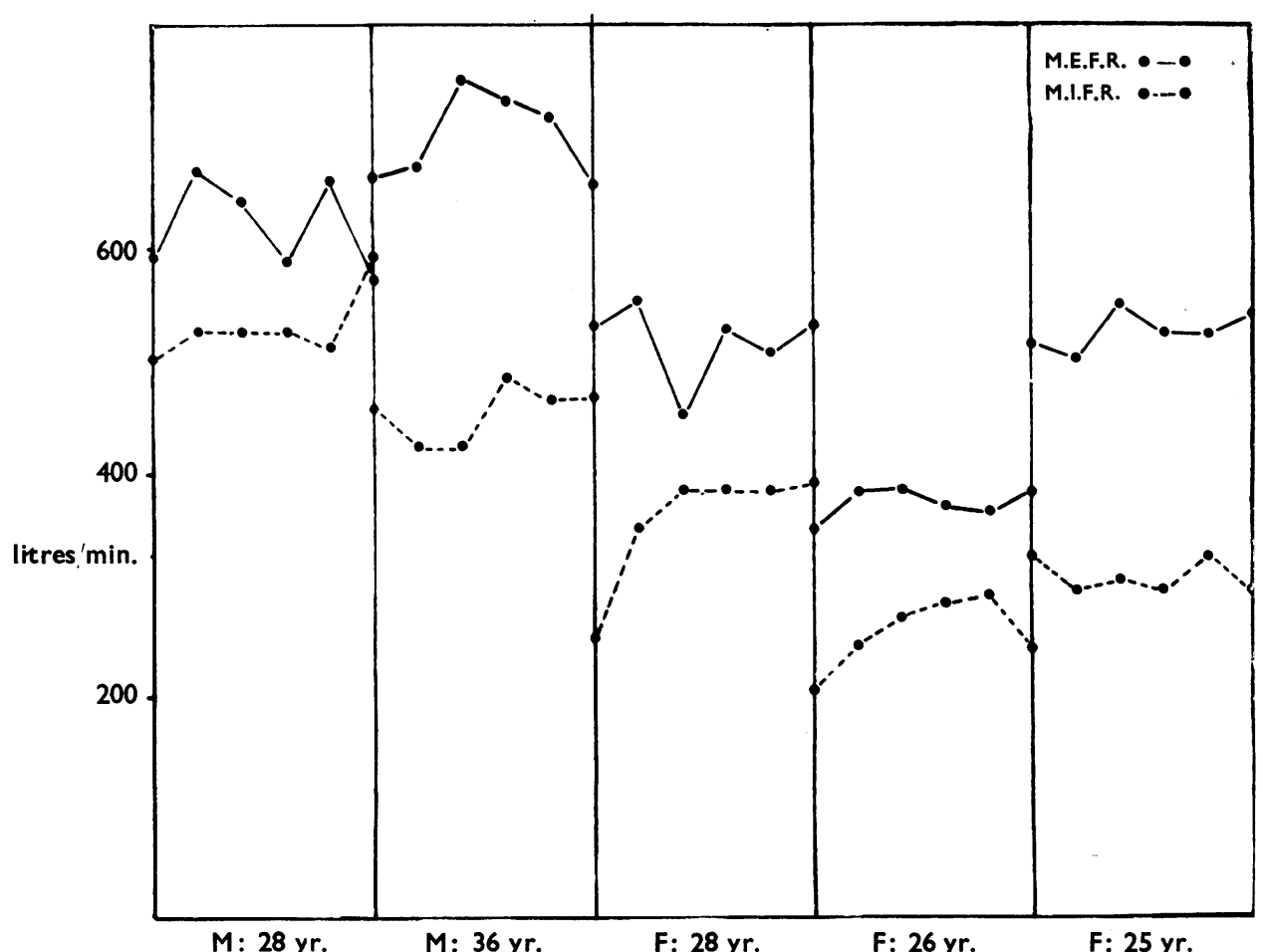

FIG. 3.-Six consecutive values for M.E.F.R. and M.I.F.R. in each of five normal subjects. 
TABLE I

MAXIMUM FLOW RATES IN PATIENTS WITH PNEUMOCONIOSIS

\begin{tabular}{|c|c|c|c|c|c|c|}
\hline & \multicolumn{6}{|c|}{ Dyspnoea Grade } \\
\hline & I & II & III & IV & $\mathbf{V}$ & Total \\
\hline No. of patients & 11 & 20 & 13 & 9 & 8 & 61 \\
\hline $\begin{array}{c}\text { (years) } \\
\text { Average }\end{array}$ & 59.0 & $55 \cdot 9$ & $54 \cdot 9$ & $60 \cdot 2$ & $60 \cdot 4$ & $57 \cdot 5$ \\
\hline $\begin{array}{l}\text { M.E.F.R. } \\
\text { (l./min.) }\end{array}$ & 320 & 255 & 175 & 65 & 45 & 193.9 \\
\hline $\begin{array}{l}\text { M.I.F.R. } \\
\text { (1./min.) }\end{array}$ & 269 & 256 & 233 & 147 & 188 & $229 \cdot 9$ \\
\hline M.I.F.R. & $1 \cdot 20$ & 1.04 & 0.77 & 0.41 & $0 \cdot 23$ & 0.816 \\
\hline
\end{tabular}

Dyspnoea grade $I=$ Performance as good as others of same age. II = Breathless on the hills or stairs. III = Unable to walk at the same speed as others, but can do one mile at own speed. IV = Unable to walk 100 yards without a rest. $V=$ Breathless on talking or dressing.

going beyond the first three trials, whereas with the M.I.F.R. better results may come with more practice. Taking the best of three trials, the mean value of the M.I.F.R. is $392 \mathrm{l} . / \mathrm{min}$., whereas with the best of six it is $4151 . / \mathrm{min}$. This difference is not statistically significant. The average value of the M.E.F.R. goes down slightly from 543 to 541 1 ./min. as the number of trials increases from three to six, whereas the M.I.F.R. increases from 366 to $381 \mathrm{l} . / \mathrm{min}$. An analysis of variance shows that the coefficient of variation between trials in the same persons is $7.4 \%$ for the M.E.F.R. and $8.8 \%$ for the M.I.F.R. This difference is not statistically significant. An analysis of variance carried out on the data obtained from the records of the 10 patients (three measurements each of M.E.F.R. and M.I.F.R. are routinely made) shows slightly greater coefficients of variation, but the difference between M.E.F.R. (16.2\%) and M.I.F.R. (12.5\%) is again not statistically significant.

The results of the best measurements made in the 61 miners with pneumoconiosis are shown in Table I. There is no significant difference in the mean age of the men in the five dyspnoea grades. An analysis of covariance with age shows that the effect of age is very slight and the adjustment in the figures is negligible. There is a fall in M.I.F.R. with dyspnoea grade, except for grade 5, which is just significant at the $5 \%$ level, but the fall in M.E.F.R. and the ratio $\frac{\text { M.E.F.R. }}{\text { M.I.F.R. }}$ are both highly significant at the $0.1 \%$ level. Tables II and III show the results of

TABLE II

VOLUMES EXPELLED WITH VARYING EFFORT IN NORMALS

\begin{tabular}{|c|c|c|c|c|c|}
\hline Subject & Sex & $\begin{array}{l}\text { Age } \\
\text { (Yr.) }\end{array}$ & $\begin{array}{c}\text { Surface } \\
\text { Area } \\
\text { (sq. m.) }\end{array}$ & $\begin{array}{c}\text { Volume } \\
\text { Expelled in } \\
1 \text { Second } \\
(\mathrm{ml} .)\end{array}$ & $\begin{array}{c}\text { Max. } \\
\text { Oesophageal } \\
\text { Pressure } \\
\left(\mathrm{cm} . \mathrm{H}_{2} \mathrm{O}\right)\end{array}$ \\
\hline T.W. & $\mathbf{M}$ & 64 & 1.55 & $\begin{array}{r}1,856 \\
1,846 \\
1,856 \\
1,476 \\
759\end{array}$ & $\begin{array}{r}134 \\
103 \\
80 \\
43 \\
11\end{array}$ \\
\hline W.W. & $\mathbf{M}$ & 38 & 1.84 & $\begin{array}{l}4,919 \\
5,016 \\
4,967 \\
3,234\end{array}$ & $\begin{array}{l}97 \\
75 \\
51 \\
11\end{array}$ \\
\hline T.O. & $\mathbf{M}$ & 31 & 1.69 & $\begin{array}{l}2,834 \\
2,935 \\
2,833 \\
2,834 \\
2,530\end{array}$ & $\begin{array}{r}148 \\
148 \\
82 \\
78 \\
51\end{array}$ \\
\hline
\end{tabular}

TABLE III

VOLUMES EXPELLED WITH VARYING EFFORT IN EMPHYSEMA

\begin{tabular}{|c|c|c|c|c|c|c|c|c|c|}
\hline Diagnosis & Sex & $\begin{array}{l}\text { Age } \\
\text { (Yr.) }\end{array}$ & $\begin{array}{l}\text { Surface } \\
\text { Area } \\
\text { (sq. m.) }\end{array}$ & $\begin{array}{l}\text { Vital } \\
\text { Capacity } \\
\text { (ml.) }\end{array}$ & $\begin{array}{l}\text { Indirect } \\
\text { M.B.C. } \\
\text { (1./min.) }\end{array}$ & $\begin{array}{l}\text { M.E.F.R. } \\
(1 . / \min .)\end{array}$ & $\begin{array}{l}\text { M.I.F.R. } \\
\text { (1./min.) }\end{array}$ & $\begin{array}{l}\text { Volume } \\
\text { Expelled in } \\
1 \text { Second } \\
(\mathrm{ml} .)\end{array}$ & $\begin{array}{c}\text { Max. } \\
\text { Oesophageal } \\
\text { Pressure } \\
\left(\mathrm{cm} . \mathrm{H}_{2} \mathrm{O}\right)\end{array}$ \\
\hline $\begin{array}{l}\text { T.A. } \\
\text { Chronic bronchitis and } \\
\text { emphysema }\end{array}$ & $\mathbf{M}$ & 61 & 1.51 & $\begin{array}{l}2.396 \\
(2,720)\end{array}$ & $\begin{array}{l}30 \\
(90)\end{array}$ & 22 & 226 & $\begin{array}{r}512 \\
466 \\
543 \\
605 \\
931 \\
1,009 \\
892\end{array}$ & $\begin{array}{r}312 \\
307 \\
307 \\
242 \\
113 \\
85 \\
72\end{array}$ \\
\hline $\begin{array}{lll}\text { C.P. } & \ldots & \\
\text { Emphysema } & & \end{array}$ & $\mathbf{M}$ & 50 & 1.65 & $\begin{array}{c}2,986 \\
(3,655)\end{array}$ & $\begin{array}{c}38 \\
(127)\end{array}$ & 51 & 168 & $\begin{array}{l}774 \\
886 \\
991 \\
992\end{array}$ & $\begin{array}{r}140 \\
137 \\
80 \\
44\end{array}$ \\
\hline $\begin{array}{l}\text { A.J. } \\
\text { Chronic bronchitis and } \\
\text { emphysema }\end{array}$ & $\mathbf{M}$ & 66 & $1 \cdot 23$ & - & $\begin{array}{c}23 \\
(93)\end{array}$ & 19 & - & $\begin{array}{l}560 \\
600 \\
560 \\
680\end{array}$ & $\begin{array}{r}119 \\
109 \\
28 \\
27\end{array}$ \\
\hline $\begin{array}{l}\text { A.C. } \\
\text { emphysema }\end{array}$ & $\mathbf{M}$ & 59 & 1.65 & $\begin{array}{c}2,830 \\
(2,955)\end{array}$ & $\begin{array}{r}34 \\
(107)\end{array}$ & 40 & 182 & $\begin{array}{l}534 \\
712 \\
890 \\
801 \\
623\end{array}$ & $\begin{array}{r}122 \\
107 \\
85 \\
66 \\
50\end{array}$ \\
\hline
\end{tabular}




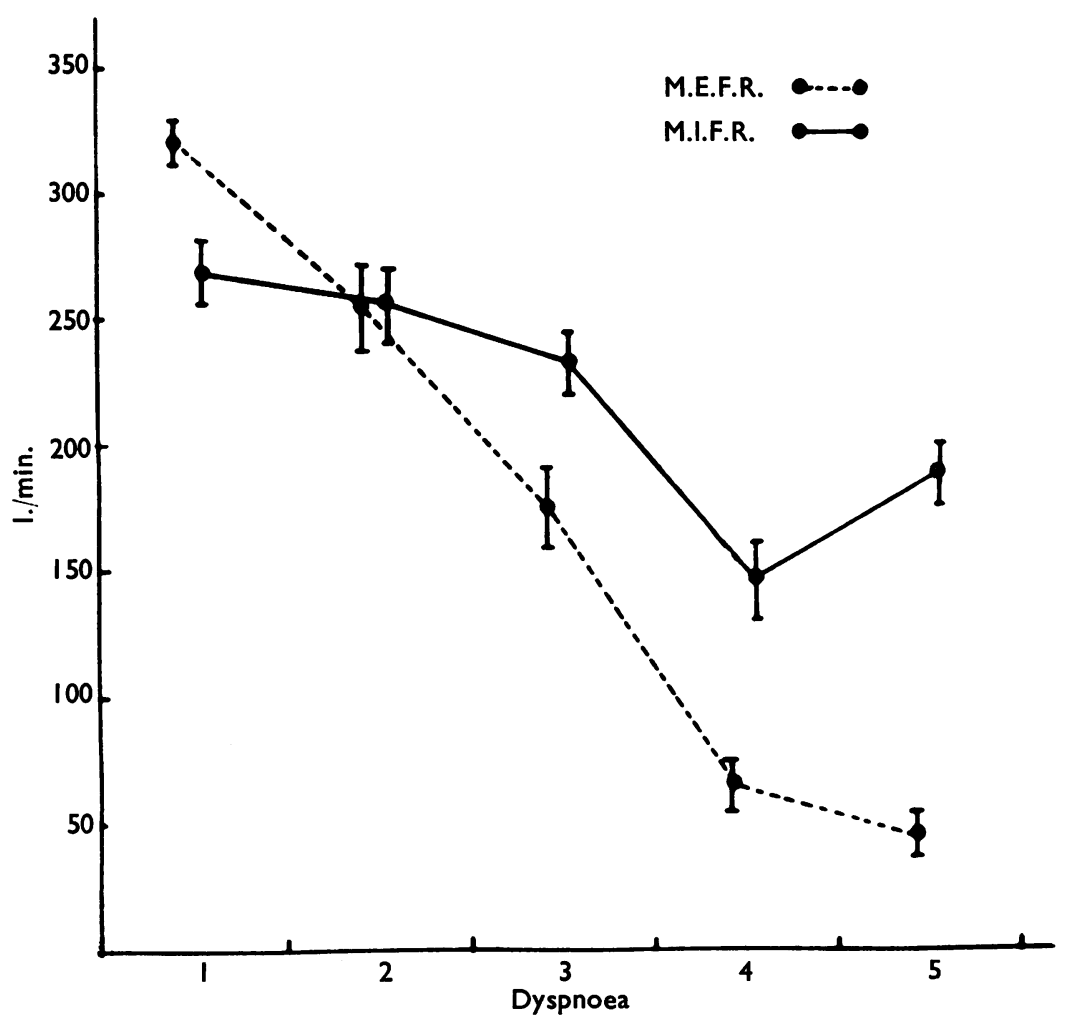

Fig. 4.-Mean M.E.F.R. and M.I.F.R. with standard error, plotted against dyspnoea grade in patients with pneumoconiosis. Note change in relative values with increase in dyspnoea.

variation in expiratory effort, as reflected by the intrathoracic pressure, on the volume expelled in one second in three normal subjects and four emphysematous patients. Above a certain pressure there is no increase in volume with increase in pressure in normals, whereas in the emphysematous patients there is often a decrease in volume with an increase in pressure.

\section{Discussion}

From the point of view of instructing the patient we have found that it is only a little more difficult to obtain inspiratory spirograms than to obtain the more usual expiratory spirogram and the variance in both normals and patients is similar. Our normal values are comparable to those quoted by Comroe and others (1955). No attempt has been made to establish normal values for sex, age, and size, nor indeed have these yet been published.

In normals and in patients with little or no disability, it appears that the combination of muscular forces and airway resistance favours expiration, since, over the range of measurement, the M.E.F.R. is slightly higher than the M.I.F.R. (Figs. 3 and 4). Briscoe and Dubois (1958) have shown by specific measurements of airway resistance, using the uninterrupted flow technique of the body plethysmograph, that airway resistance is less at greater lung volumes in any one individual. The airways widen and lengthen on inspiration (Heinbecker, 1927; Macklin, 1929) and the net effect is a reduction in resistance. Since the M.E.F.R. is measured from a volume close to full inspiration or total lung capacity, and the M.I.F.R. from a volume close to full expiration or residual volume, the difference in normals may be explained by the effect of lung volume on airway resistance.

When a ventilatory defect develops, however, a striking reversal in this relationship occurs (Fig. 2) and expiration becomes slow and difficult and inspiration relatively much easier to perform. That this alteration is significantly related to disability can be seen from the values obtained in the miners with pneumoconiosis (Figs. 4 and 5). They formed a homogeneous group in respect of 


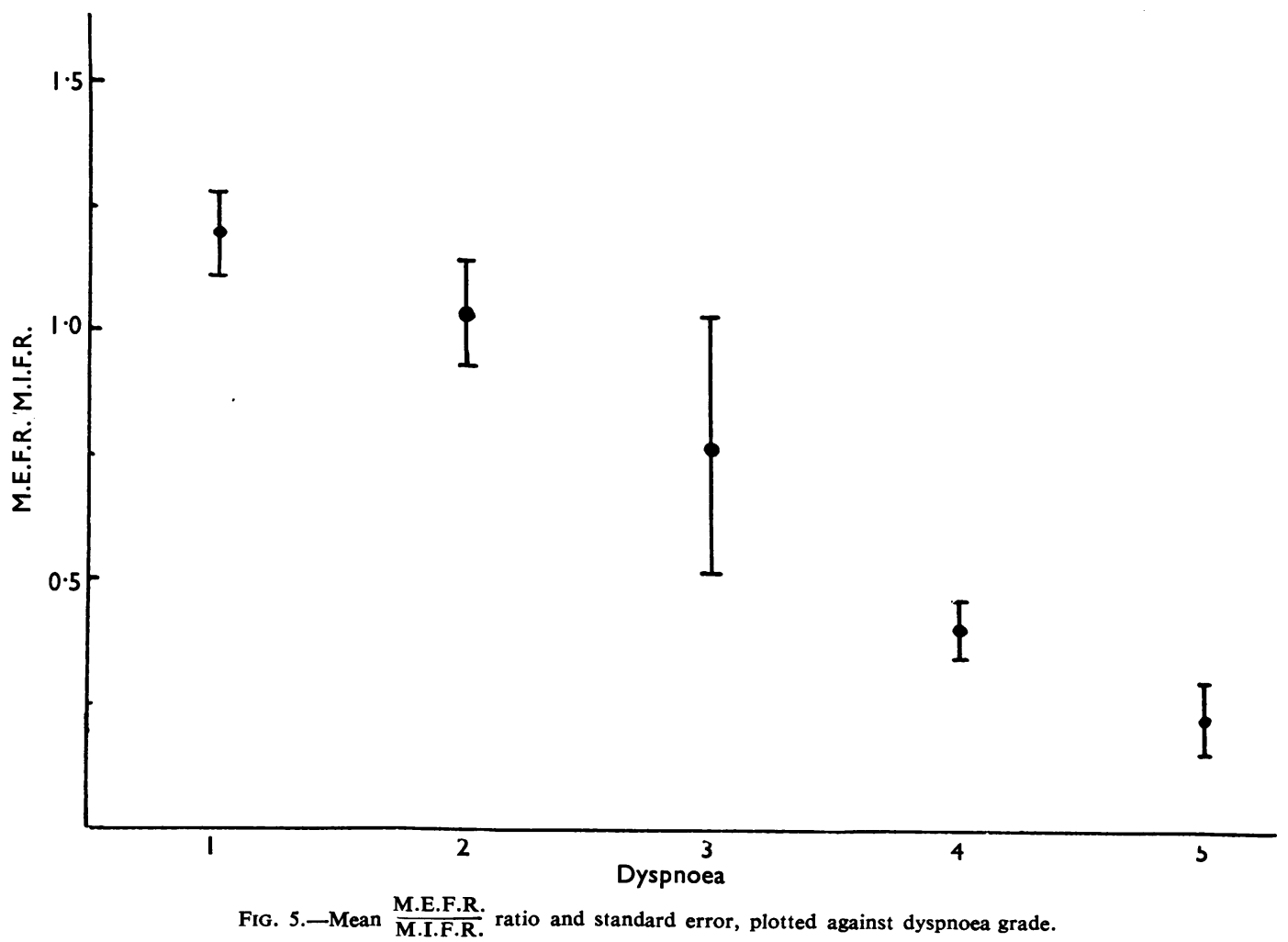

sex, age, and occupation, but the grades of pneumoconiosis and incidence of complicating chronic bronchitis varied considerably. With an increase in dyspnoea there was a significant fall in M.E.F.R., indicating the development of a ventilatory defect. The M.I.F.R. level on the other hand remained relatively stable, even with a severe impairment in M.E.F.R., and consequently the usual $\frac{\text { M.E.F.R. }}{\text { M.I.F.R. }}$ ratio is completely reversed. This we interpret as due to structural changes in the lung resulting from emphysema. Dayman (1951) and Fry, Ebert, Stead, and Brown (1954) have previously shown a greater airway resistance in expiration in emphysematous patients and Campbell, Martin, and Riley (1957) have advanced a convincing theoretical explanation. The basic concept is that as a result of the loss of elastic tissue, there is an inward collapse of the bronchial walls when the intrathoracic pressure rises in expiration. The loss of elastic tissue contributes to this collapse in two ways: (1) by the failure of the alveolar walls to impart their normal quota of intra-alveolar and hence intrabronchial pressure to maintain the gradient across the bronchial walls; (2) by the loss of elastic support of the bronchial walls themselves, rendering them less able to resist inward collapse. Inspiration on the other hand is not affected by
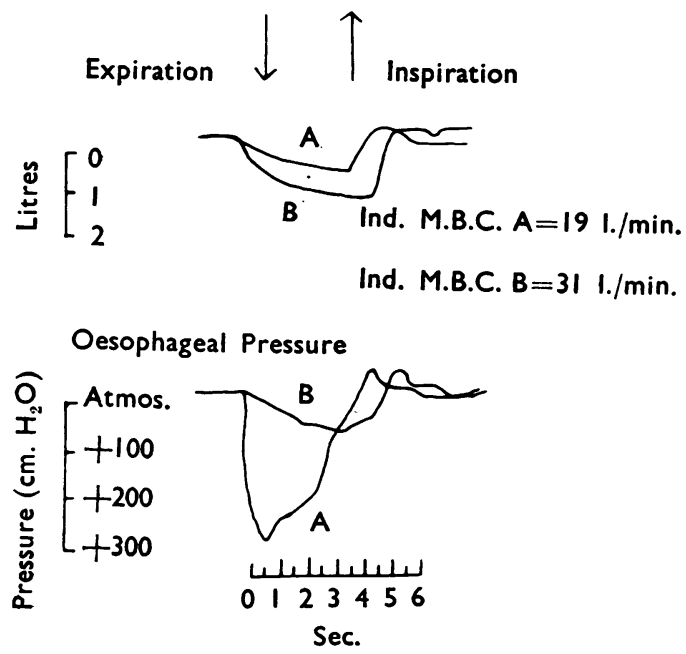

FIG. 6.-Spirograms with varying intrathoracic (oesophageal) pressure in emphysematous patient. The better spirogram $B$ is obtained with the lesser pressure. The difference in measurement of indirect M.B.C. is considerable. 


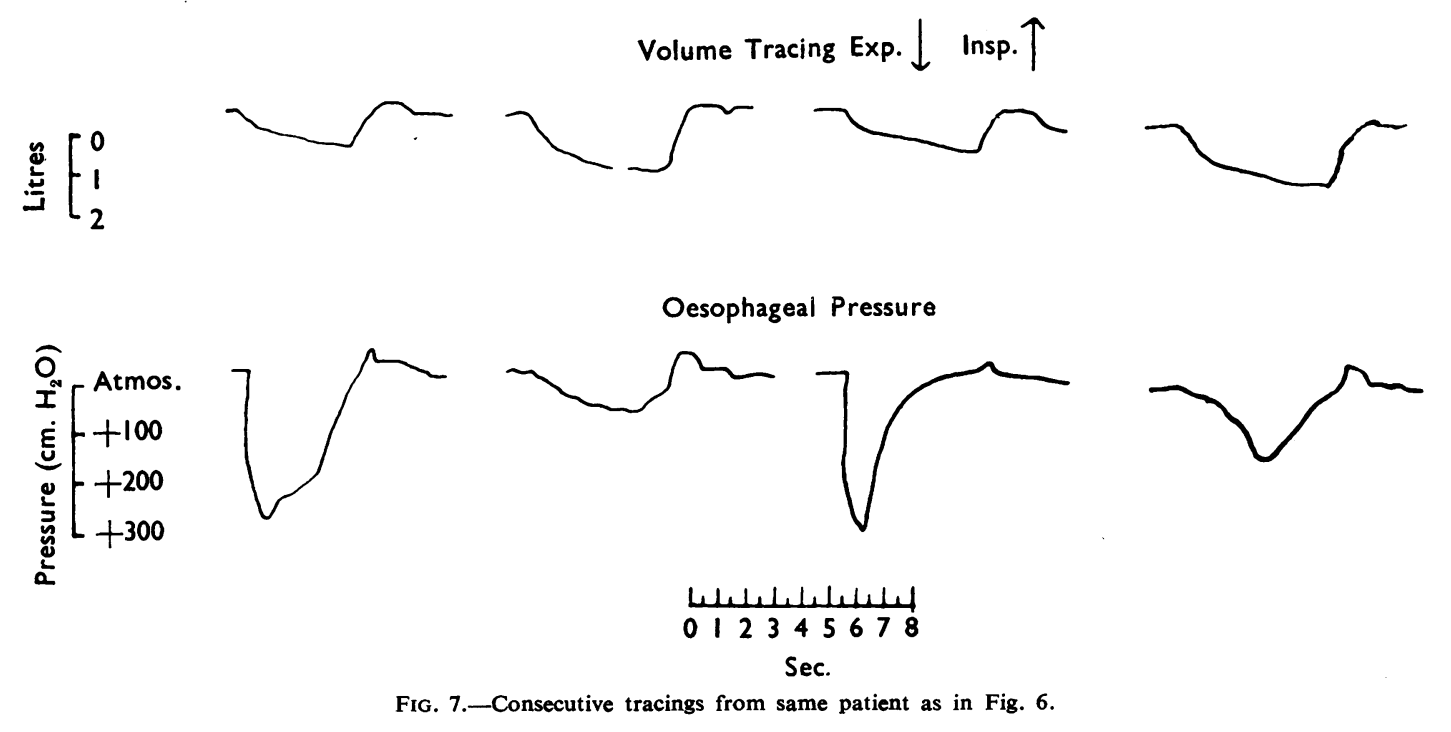

these mechanisms and the forces are all directed towards keeping the walls open.

In patients showing a marked discrepancy between M.E.F.R. and M.I.F.R., it is possible to demonstrate this check valve mechanism by the measurement of expiratory flow rates with varying degrees of effort. Measurements obtained in four patients with emphysema are given in Table III. The volumes expired in one second are quoted - because the volume expired during the first second of a forced expiration (F.E.V..$_{1.0}$ ) is so frequently measured in routine work. The maximum intrathoracic pressures reached during the first second are listed with the expired volume, and it is seen that in the emphysematous patients, although the relationship is not strictly constant, smaller volumes may be expelled with the greater pressures. There is a lower limit below which the volume expelled is less with less pressure. In normals, on the other hand (Table II), a volume plateau is reached over a fairly wide range of pressures and below this a further fall in pressure results in a smaller one-second volume. This has also been reported by McDermott and McKerrow (1956) and it explains why the F.E.V. is so reproducible in normals. Although it is to a greater extent pressure-dependent in emphysematous patients, the F.E.V. will still be a reproducible measurement and will still correlate well with disability, provided the maximum effort is made by the patient. It will not, however, necessarily be the largest possible one-second volume, obtained by the optimal intrathoracic pressure, that the patient can achieve ; and it may differ from this value by as much as $100 \%$ (T.A. in Table III).

Certain clinical features noted in patients with severe emphysema are explained by the bronchial collapse mechanism. Their wheezing fails to respond to spasmolytic drugs and is constant and fixed, unlike that due to pure asthma. During exercise or an acute respiratory infection when the work of breathing increases, the collapse mechanism is more pronounced because of the greater respiratory pressures developed, and patients commonly adopt the trick of pursing their lips on expiration to raise the intrabronchial pressure. The bronchial collapse mechanism and other causes of increase in airway resistance, such as smooth muscle spasm, secretions and mucosal oedema, may, of course, coexist, and probably frequently do. In such cases the effect of spasmolytic drugs on expiratory and inspiratory flow rates may well give valuable additional information.

\section{SUMmARY}

The maximum expiratory and inspiratory flow rates (M.E.F.R. and M.I.F.R.) have been measured spirometrically according to the method of Danzig and Comroe.

Normally the M.E.F.R. has a higher value than the M.I.F.R., but with the development of a ventilatory defect the relationship is completely reversed. This ratio reversal is highly significant when related to the degree of dyspnoea.

The abnormal physiological basis for the ratio reversal is discussed. In patients who show it, emphysema is to be suspected. 
In such patients a maximum expiratory effort may produce a one-second volume considerably below that which could be achieved by a lesser effort.

We wish to thank Dr. D. J. Cameron for his valuable assistance in the early stages of this study, Dr. W. A. Wilson for the statistical analysis, and Dr. R. M. L. Weir (Kirkcaldy) and Dr. J. W. Fraser (Dunfermline), who referred many of the patients for assessment.

\section{REFERENCES}

Briscoe, W. A., and Dubois, A. B. (1958). J. clin. Invest., 37, 1279. Campbell, E. J. M., Martin, H. B., and Riley, R. L. (1957). Bull. Johns Hopk. Hosp., 101, 329.

Comroe, J. H., Forster, R. E., Dubois, A. B., Briscoe, W. A., and Carlsen, E. (1955). The Lung, p. 127. The Year Book Publishers, Chicago.

lishers, Chicago.
Danzig, L., and Comroe, J. H. Unpublished.

Dayman, H. (1951). J. clin. Invest., 30, 1175.

Fry, D. L., Ebert, R. V., Stead, W. W., and Brown, C. C. (1954). Amer. J. Med., 16, 80 .

Heinbecker, P. (1927). J. clin. Invest., 4, 459.

Macklin, C. C. (1929). Physiol. Rev., 9, 1 .

McDermott, M., and McKerrow, C. B. (1956). XXth International Physiological Congress, Brussels; Abstracts of Communications, p. 628 . 